\title{
Resistencia a la helada de los productos de cerámica roja
}

\author{
M.V.V. RAMIRES ${ }^{1}$, T. P. MADRUGA ${ }^{2}$ Y C.P. BERGMANN ${ }^{2}$ \\ ${ }^{1}$ Unisinos - Centro de Ciências Exatas e Tecnológicas. 93022-000 - S. Leopoldo, RS - Brasil \\ ${ }^{2}$ Universidade Federal do Rio Grande do Sul 90035-190 - Porto Alegre, RS - Brasil
}

\begin{abstract}
Se estudia la degradación que sufre la cerámica roja cuando se expone a la acción de los climas fríos e húmedos. La experimentación se ha realizado con cuatro arcillas de la son expuestas a los climas fríos y húmedos. Se investigaron cuatro diferentes arcillas de la provincia del Rio Grande do Sul, que se emplean tradicionalmente en la fabricación de tejas. Dos de ellas pertenecen a la formación de la Serra Geral y las otras dos de la formación Estrada Nova. La caracterización de las arcillas ha incuido: composición química y mineralógica, granulometría, plasticidad, humedad de moldeo, contracción lineal de secado e resistencia a la flexión de piezas secas. Las probetas han sido moldeadas por prensado, y cocidas a $850^{\circ}, 900^{\circ}, 950^{\circ}$ y $1000^{\circ} \mathrm{C}$ con tres tiempos de permanencia a la temperatura máxima (3, 12 y 24 horas). En las probetas cocidas se ha determinada la capacidad de absorción de agua, la densidad total, la porosidad abierta, la distribución del tamaño de los poros y la resistencia a la flexión en cuatro puntos. En el estudio del comportamiento a los ciclos de congelación-descongelación, ha incluido, además de la ciclación de las probetas, la determinación de sus coeficientes de saturación y el análisis microestructural, por microscopia electrónica de barrido, de probetas de probetas que han sufrido la ciclación. Apoyándose en los datos obtenidos, los autores presentan un modelo para el mecanismo de degradación, y sugieren un factor de degradación, que relaciona el volumen total de mesoporos con su tamaño medio. Según este modelo, los productos cerámicos de arcilla, que tienen una lata probabilidad de ser resistentes a los ciclos de congelación - descongelación, son aquellos cuyo factor de degradación es menor de 100.
\end{abstract}

Palabras clave: cerámica estructural, cerámica roja, tejas, resistencia a la helada.

\section{Frost-resistance of red ceramic products}

The present work is a study about degradation occurring with red ceramics whenever they are exposed to the environmental conditions of a cold and humid climate. Four different types of clay from Rio Grande do Sul were studied: two of them from the Serra Geral formation, and the other two from the formation of Strada Nova, which are commonly used to make roof tiles. The clay was characterised to identify its chemical and mineralogical composition. Also the physical properties were researched. In the ceramic processing, the pressure with four different sintering temperatures $\left(850^{\circ} \mathrm{C}, 900^{\circ} \mathrm{C}, 950^{\circ} \mathrm{C}\right.$, and $\left.1000^{\circ} \mathrm{C}\right)$ at three different intervals $(3,12$, and 24 hours) were used. The ceramic materials thus obtained were characterised according to their physical properties (water absorption, total density, porosity, and porous size), and mechanical (mechanical resistance over four points). For the characterisation of the degradation mechanism, some trials were carried out to obtain the coefficient of saturation and on frost and defrost cycles. The microstructural analysis was made with a scanning electronic microscopy. On the basis of the results obtained, a model for the degradation mechanism is presented, and a degradation factor which relates the total volume of mesopores to the standard size of mesopores is suggested. It was concluded that the red ceramic products more prone to be frost-resistant are those presenting a degradation factor below 100 .

Key works: structural ceramic, red ceramic, roof tiles, frost resistance.

\section{INTRODUCCIÓN}

Los productos de arcilla cocida tienen un uso bien acreditado como materiales de construcción y, por tanto, se espera de ellos que sean durables. Estos materiales, por ser porosos, absorben humedad del ambiente $y$, en regiones donde hace mucho frío, como en el sur del Brasil, pueden ser dañados por la acción de la congelación y descongelación.

La resistencia a estas acciones del hielo, por exposición ambiental, es uno de los principales factores que determinan la calidad de los materiales porosos de construcción, tales como las tejas, baldosas o ladrillos de arcilla cocida.

La relevancia de esta propiedad en durabilidad de los productos de arcilla cocida, exige conocer cuáles son y cómo actúan los factores que inciden sobre la degradación. La

\section{INTRODUCTION}

The red ceramic products are widely used in construction and therefore, among other qualities, they must be durable. As those materials are porous, they absorb the environmental humidity and, in very cold regions, such as in the South of Brazil, they suffer an erosion due to the frost and defrost action.

The resistance to frost actions, by environmental exposition, constitutes one of the main factors determining the quality of porous construction materials, such as roof tiles, floor tiles or fired clay bricks.

The relevance of this property on fired clay products durability, requires knowing which are the factors that affect degradation. Frost-resistance, most of the times, is evaluated 
resistencia al hielo se avalúa, frecuentemente, por inspección visual de las probetas, después de haber sufrido la ciclación de congelación - descongelación. Estas inspecciones visuales permiten, en efecto, detectar la degradación de los materiales, pero no esclarecen las causas.

En la actualidad, los medios científicos e industriales están dedicando una especial atención al estudio de la previsión de la vida útil de los materiales de construcción y al desarrollo de mejores métodos y técnicas de ensayo.

En el presente trabajo se propone un modelo de mecanismo de degradación, debido por la acción del hielo, y una metodología que permite evaluar con más rapidez el comportamiento de los materiales. Los resultados experimentales que han hecho posible la presentación de estas dos propuestas, fueran analizados y discutidos por Ramires ${ }^{(01)}$.

\section{ANTECEDENTES}

En la molécula de agua coexisten enlaces iónicas y covalentes. Debido a las diferencias en los centros de las cargas del hidrógeno y del oxígeno, el protón del íon de hidrógeno cargado positivamente, atrae los electrones, cargados negativamente de otras moléculas de agua. Esta fuerza de atracción, relativamente débil, que se llama de enlace por puente de hidrógeno, es la responsable de la estructura ordenada del agua ${ }^{(02)}$.

El agua, al pasar del estado líquido al sólido, cristaliza según la estructura que se presenta en la Fig. 1. Analizando esta figura, se observa que cada molécula de agua, en la estructura del hielo, está cercada por otras cuatro, formando grupos en los cuales una molécula está rodeada por otras cuatro, formando grupos en los cuales una molécula está en el centro de un tetraedro y las otras cuatro en sus vértices. Tanto las moléculas, como los grupos de moléculas, se mantienen unidos por puentes de hidrógeno.

En el momento en que el hielo funde a $0^{\circ} \mathrm{C}$, ocurre la ruptura de aproximadamente de $15 \%$ de los enlaces de hidrógeno, y por ese motivo, cada molécula de agua puede adquirir cuatro vecinos próximos más, haciendo aumentar la densidad de $0,920 \mathrm{~g} / \mathrm{cm}^{3}$ para $1 \mathrm{~g} / \mathrm{cm}^{3}$. En el proceso inverso, es decir, al solidificarse el agua, se produce una expansión en lugar de una contracción ${ }^{(02)}$.

Según Winhler ${ }^{(03)}$, el agua a la temperatura ambiente, cuando se compara con la estructura del hielo, tiene rotos, aproximadamente, el cincuenta por ciento de los enlaces de hidrógeno. Debido a ese gran número de enlaces rotos, el agua presenta cargas superficiales desequilibradas, que generan energía de superficie y, en consecuencia, una tensión superficial.

En los sólidos porosos, la energía superficial debida a las cargas superficiales desequilibradas, depende de la extensión de la superficie y, por tanto, cuanto más fina sea la porosidad, mayor será la energía superficial total del sólido.

Si el agua fuera capaz de pene-

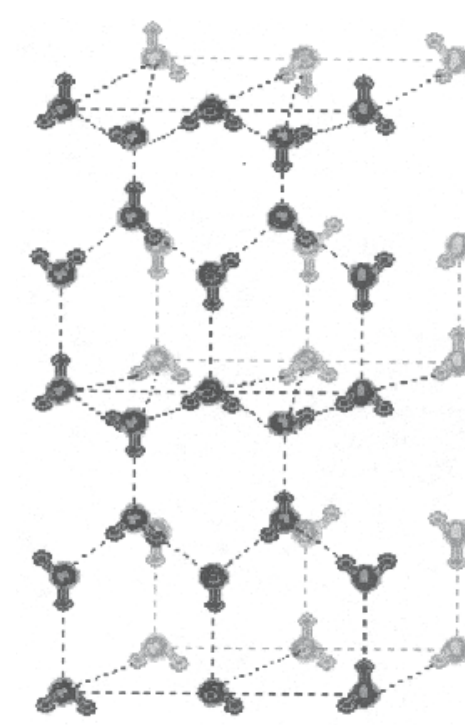

by a visual analysis of the sample after long on frost and defrost trials. Indeed, these visual analysis allow detecting materials degradation, but do not clarify the cause.

Nowadays, the scientific and industrial world are paying a great attention to the study of the materials useful life forecast and to the development of better methods and technical trials.

This work presents the proposal of a degradation mechanism model and a methodology for the quick evaluation the behaviour

Figura 1: Estructura del hielo ${ }^{(02)}$. of those materials. The experiFigure 1: structure of the ice ${ }^{(02)}$. mental results that make possible the presentation of these two proposals were analysed and discussed by RAMIRES $^{(01)}$.

\section{BIBLIOGRAPHICAL REVIEW}

In a water molecule, ionic and covalent bonds coexist. Due to the differences in the hydrogen and oxygen charge centres, the hydrogen ion proton positively charged attracts the negatively charged electrons from other water molecules. This relatively weak attractive force is called binding by hydrogen bonds is responsible for the water ordered structure ${ }^{(02)}$.

Water, when passing from a liquid to a solid state (ice), crystallises according to the structure presented in Figure 1.

When analysing this figure, it can be observed that each water molecule in the ice structure is surrounded by other four molecules, forming groups in which a molecule is situated in the centre of a tetrahedron and the other four in the

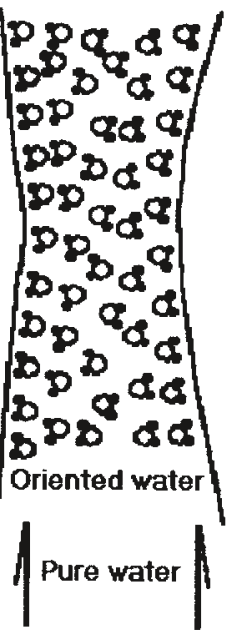

Figura 2: Estructura de las moléculas de agua orientadas en un poro ${ }^{(03)}$ Figure 2: Structure of the oriented water molecules in a pore. angles. The molecules as well as the molecule groups stay together by means of the hydrogen bonds.

At the very moment when ice melts at $0^{\circ} \mathrm{C}$, the breakage of about fifteen per cent of the hydrogen bonds occurs. For this reason, each water molecule can acquire four more close neighbours, increasing the density from $0,920 \mathrm{~g} / \mathrm{cm}^{3}$ to 1 $\mathrm{g} / \mathrm{cm}^{3}$. When the inverse process takes place, an expansion occurs instead of a contraction ${ }^{(02)}$.

According to WINHLER ${ }^{(03)}$, water at room temperature, when compared to ice structure, has approximately fifty per cent of the hydrogen bonds broken. Due to this great number of broken bonds, water presents unbalanced surface charges, which generate surface energy and, consequently, surface 
trar en estos poros, y si las fuerzas de atracción en la superficie de los poros fueran suficientemente intensas para romper la tensión superficial de la masa del agua, las moléculas de agua se colocarían formando una estructura orientada, semejante a la estructura del hielo. El agua, así orientada, tendrá una densidad menor que el agua en estado libre y, por tanto, necesitará un espacio mayor y causará una tensión interna el poro ocupado (Fig. 2).

\section{MATERIALES Y MÉTODOS}

\subsection{Materias Primas}

Las arcillas estudiadas en este trabajo proceden de cuatro localidades diferentes, y se denominan: 1) Arcilla 100. Bento Gonçalves (color marrón). 2) Arcilla 200. Bom Princípio (coloración rojo oscuro). 3) Arceilla 300. Gravataí (color rojo claro) y 4) Arcilla 400. Gravataí (coloración rojo medio).

Las muestras de estas arcillas se secaron al aire durante 48 horas, y se molieron hasta lograr que la totalidad pasase por el tamiz $\mathrm{ABNT}^{\circ} 80$ (abertura 0,177 mm).

\subsection{Fabricación de los cuerpos de prueba}

Las probetas fueron moldeadas por prensado uniaxial simple de la arcilla humedecida. Su contenido en agua era el equivalente a la mitad del límite de plasticidad.

De cada uno de los tipos de arcilla, se moldearon probetas de $60 \times 20 \times 10 \mathrm{~mm}$, y se secaron al aire durante un tiempo mínimo 48 horas. A continuación se secaron en estufa a $110^{\circ} \mathrm{C}$ por 24 horas, y se cocieron a $850^{\circ}, 900^{\circ}, 950^{\circ}$ y $1000^{\circ} \mathrm{C}$, con tres distintos tiempos de permanencia a la máxima temperatura $(3,12$ y $24 \mathrm{~h})$.

\subsection{Determinación de la resistencia a la congelación}

La resistencia al congelamiento se determinó aplicando ciclos de congelación - descongelación multi-direccional, que es el método tradicional adoptado por la mayoría de las normas existentes(04).

En este ensayo se utilizaron 10 probetas, las cuales, después de ser descongeladas, fueron secadas en estufa, enfriadas, pesados y examinadas cuidadosamente en busca de fisuras. Se definida la fisura como una separación que es visible por una persona con visión normal, a una distancia de $30 \mathrm{~cm}$, bajo una iluminación de no menos de 50 lux ${ }^{(05)}$. La longitud total de la fisura se marca con un rotulador de tinta indeleble.

Después de esta inspección, las probetas se sumergieron en un tanque con agua limpia a $24 \pm 5,5^{\circ} \mathrm{C}$ y se mantuvieran durante $4 \pm 1 / 2$ hora. A continuación, se colocaran las probetas en bandejas de tamaño apropiado para poder estar completamente sumergidas, y se mantuvieron en una cámara de congelación durante $20 \pm 1$ horas. Esta cámara estaba preparada para mantener la temperatura del aire por debajo de $-9^{\circ} \mathrm{C}$ en el compartimento de congelación. Una hora después de puesta la carga máxima de unidades - que inicialmente estaban a una temperatura no superior a $32^{\circ} \mathrm{C}$ - se sacaron las bandejas de la cámara de congelación, y se sumergieron totalmente en el tanque de descongelación, con agua a $24 \pm$ $5,5^{\circ} \mathrm{C}$ por $4 \pm 1 / 2$ hora. Este ciclo de congelación - descongelación se repitió hasta 50 veces. tension.

In porous solids, the surface energy caused by the unbalanced surface charges depends on the surface area. Therefore, the lower the porosity is, the greater the total surface energy of the solid becomes.

If water were capable of penetrating into those pores, and if the attraction forces on the pores surface were intense enough to break the surface tension of the water mass, and shapes these water molecules would place themselves forming an oriented structure, similar to the ice structure. This water will have a lower density than free water. In this way, water will need more room, causing an internal tension in the occupied pore (Figure 2).

\section{MATERIALS AND METHODS}

\subsection{Raw materials}

The types of clay studied in this work come from four different places, and are called 1) Clay 100. Bento Gonçalves (brown colour). 2) Clay 200. Bom Princípio (dark red colour). 3) Clay 300. Gravataí (light red colour). And 4) Clay 400. Gravataí (medium red colour).

Those samples were open air dried for 48 hours, and ground in a mill until all the samples went through the sieve ABNT $n^{\circ} 80$ (opening 0,177 mm).

\section{2 Specimens manufacture}

The specimens were shaped by uni-axial simple pressing of the humidified clay. Its water content was the equivalent of half the plasticity limit.

Specimens with a size of $60 \times 20 \times 10 \mathrm{~mm}^{3}$, open air dried for a minimum of 48 hours, were conformed for each type of clay. After this, they were oven dried at $110^{\circ} \mathrm{C}$ for 24 hours, and then, sinterized at $850^{\circ} \mathrm{C}, 900^{\circ} \mathrm{C}, 950^{\circ} \mathrm{C}$, and $1000^{\circ} \mathrm{C}$ with different kinds of maximum temperature stay (3, 12 and 24 hours).

\subsection{Frost-resistance determination}

Frost-resistance was determined by multi-directional frosting-defrosting cycles. Being this the traditional method proposed by most of the actual regulations(04).

In this trial, the 10 specimens were used, which after being oven dried, were oven dried, cooled down, weighed and carefully examined looking for fissures. A fissure is defined as a separation able to be seen by a person with a normal visual capacity at a distance of $30 \mathrm{~cm}$ under a lighting above $50 \mathrm{lux}^{(05)}$. The total length of the fissure is marked with a marking ink pen.

After this examination, the specimens were submerged in a tank with clean water at $24 \pm 5,5^{\circ} \mathrm{C}$ for $4 \pm 1 / 2$ hours. Later, the specimens were set on a board with enough size and bottom for them to be completely submerged, putting them into a frosting cabinet for $20 \pm 1 / 2$ hours. This cabinet was prepared to keep the air temperature below $-9^{\circ} \mathrm{C}$. An hour after filling it with the maximum load of units, at a temperature, initially, below $32^{\circ} \mathrm{C}$, the boards were removed from the frosting chamber. and were totally submerged in the defrosting tank, with some water, kept at a temperature of $24 \pm$ 
Tras completar los 50 ciclos de congelación - descongelación, las probetas se secaron durante 24 horas, y se pasaron nuevamente, con el fin de calcular la perdida de peso como un porcentaje del peso original de la probeta seca.

En la evaluación final, se consideró que una probeta había fallado en el ensayo de congelación - descongelación, cuando ocurría una de las siguientes circunstancias: 1) pérdida de peso superior al $5 \%$; 2) rotura de la probeta en dos o más piezas significativas; 3 ) cuando existe una fisura excede en longitud a la dimensión mínima de la probeta.

\subsection{Distribución del tamaño de los poros}

El método utilizado para la obtener la distribución del tamaño de los poros fue el basado en la isoterma de adsorción de nitrógeno líquido. En este método, cuando el sólido es puesto en contacto con el nitrógeno líquido, ocurre una disminución progresiva de la presión parcial del gas y un aumento del peso del sólido. A este fenómeno, lo llamamos adsorción, y resulta de las interacciones de naturaleza física entre las moléculas del gas y los átomos de la superficie del sólido.

Para la determinar la distribución del tamaño de los mesoporos ( poros de diámetro mayor de 0,002 $\mu \mathrm{m}$ y menor que 0,05 $\mu \mathrm{m}$, se utilizó el método BJH - Barret, Joyer y Halenda(06)). Este método consiste básicamente en dividir la isoterma en varios intervalos. El valor medio de presión entre cada intervalo permite calcular el espesor de la capa adsorbida y el radio medio de los poros.

Para el cálculo de la distribución del tamaño de los microporos (de diámetro menor o igual a 0,002 $\mu \mathrm{m}$ ) se utilizó el método de Dubinin ${ }^{(07)}$, que se basa en una dependencia lineal entre el log Vp (volumen de poros) y el log P0/P (presión relativa del nitrógeno). $\mathrm{Al}$ aplicar este método, los datos experimentales se ajustan a una recta, cuya intersección con la ordenada define el volumen total de los microporos.

\subsection{Análisis de la microestructura}

La degradación microestructural que experimentan las probetas al ser sometidas a diversos ciclos de congelación descongelación, fue estudiada con el auxilio de la microscopía electrónica de barrido. $5,5^{\circ} \mathrm{C}$ for $4 \pm 1 / 2$ hours. The frosting cycle was repeated up to 50 times.

After completing the 50 frosting-defrosting cycles, the specimens were dried for 24 hours, and weighed again, with the aim of calculating the weight loss as a percentage of the dried specimen original weight.

In the final evaluation, one specimen was considered to have failed in the frosting-defrosting trial when one of the following conditions occurred: 1) weight loss over 5\%;2) breaking of the specimen in two or more significant pieces; 3) when a fissure size surpasses the specimen minimum dimension.

\subsection{Distribution of the pores size}

The method used for the obtaining of the pores size distribution was based on the liquid nitrogen adsorption isotherm. Following this method, when the solid comes in contact with the liquid nitrogen, a progressive decrease of the gas partial pressure occurs, as well as an increase of the weight of the solid. This phenomenon is called adsorption, and it stems from the interactions of a physical nature between the gas molecules and the atoms on the solid surface.

For the distribution of the mesopores size (pores with a diameter higher than $0,002 \mu \mathrm{m}$ and lower than $0,05 \mu \mathrm{m})$, the method used was BJH (Barret, Joyer Halenda (06) ). This method basically consists of dividing the isotherm in several intervals. The average pressure value on each interval allows the density of the adsorbed layer and the average ray of the pores to be calculated.

For the evaluation of the distribution of the micropores size (with a diameter smaller or equal to $0,002 \mu \mathrm{m}$ ), the method used was Dubinin's (07), which is based on a linear dependence between the $\log \mathrm{Vp}$ (volume of pores), and the $\log \mathrm{Po} / \mathrm{P}$ (nitrogen relative pressure). Following this method, the experimental data conform to a line whose intersection with the ordinate defines the total volume of the micropores.

\subsection{Analysis of the microstructure}

The microstructure degradation of the specimens submitted to several cyclical frosting and defrosting trials was analysed by scanning electronic microscopy.

\section{RESULTADOS Y DISCUSIONES}

\subsection{Modelo del mecanismo de degra- dación}

En la Fig. 3 pude apreciarse que la pieza cerámica se ha fracturado en porciones laminares, de aspecto hojaldrado, por acción de le los ciclos de congelación - descongelación. Este tipo de fractura pone en evidencia la acción direccional de las tensiones internas, que son responsables de la Figura 3: Probeta de la arcilla 400, cocida a $850^{\circ} \mathrm{C}$ degradación estructural de las piezas durante 24 horas, degradada por la acción de 10 cerámicas.

En la Fig. 4 se presenta la microes-Figure 3: Photograph of a clay 400 sample body sintructura de una pieza cerámica resis-terized at $850^{\circ} \mathrm{C}$ for 24 hours, degraded by the water tente a la helada, y en la Fig. 5 lafrosting action, after 10 frosting-defrosting cycles.

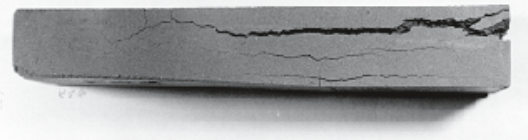

\section{RESULTS AND DISCUSSION}

\subsection{Degradation mechanism model}

The Figure 3 shows that the ceramic piece has been spilt in lamellar portions, with a puff-pastry aspect, by the action of the frost-defrost cycles. This kind of fracture proves the directional action of the internal tensions, which are responsible of the structural degradation of ceramic pieces.

In Fig. 4 and 5, microstructures of a frost-resistant ceramic, and microstructures of a non-frost-resistant ceramic are presented, respectively. When analysing Fig. 4, it can be noticed that 
microestructura de una no resistente. Cuando se analiza la Fig. 4, se observa que la cantidad de mesoporos es muy pequeña, y que no hay evidencias de fisuras, lo cual indica que la pieza no sufrió por la acción de la helada. En la Fig. 5, sin embargo, es evidente la acción de la congelación del agua en los mesoporos, los cuales resultan conectados por fisuras.

En la Fig. 6 se muestra la microestructura de la misma arcilla 400, tratada en las mismas condiciones que se indican en la Fig. 5 , pero observada $1000^{\circ} \mathrm{C}$ durante 24 horas, que ha resistido a la acción en la Fig. 5, pero observada con una de 50 ciclos de congelación - descongelación ( $\mathrm{x}$ ampliación menor (solamente x572). En 10743 )

esta Fig. son visibles las fisuras y micro-

fisuras, y se comprueba la acción del hielo a otro nivel microestrutura.

El análisis realizado sobre las microfi- defrosting cycles (10743 times).

suras, apoya la proposición de un modelo para el mecanismo de degradación. Se da por supuesto que el daño se produce porque el agua, al congelarse en los poros abiertos, causa fisuras, debido a la expansión que sufre el agua al congelarse $(9 \%$ en volumen $)^{5}$. Las fisuras formadas se propagan hasta los pequeños poros cerrados, facilitanando la saturación de estos poros. El agua, alojadas en esos poros de elevada energía superficial, posee una estructura orientada análoga a del hielo (Fig. 1) que, en su interacción con las paredes de estos poros (Fig. 2), produce microfisuras. Al unirse las diferentes microfisuras generadas en poros adyacentes, se propaga la fisura, y la
pieza tiende a agrietarse de forma lamipieza tiende a agrietarse de forma lami- $850^{\circ} \mathrm{C}$ durante 24 horas, que no ha resistido después nar, tal como se esquematiza en la Fig. 9971) 7.

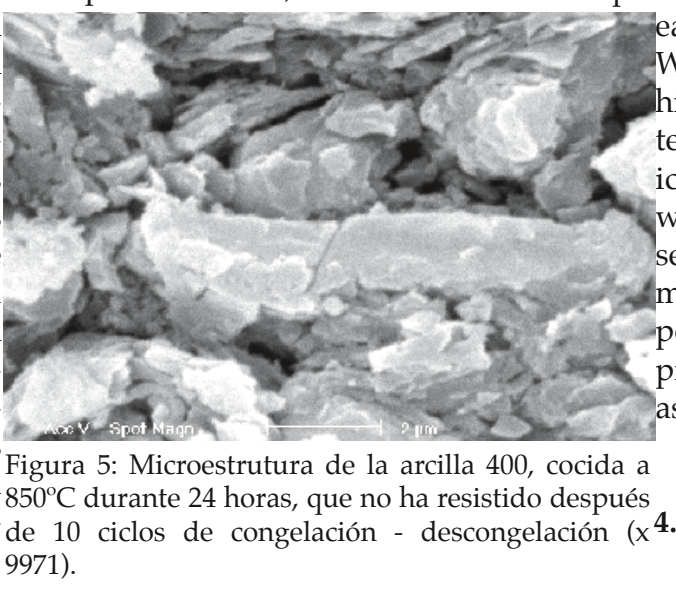
formed fissures spread to the small closed pores, making easier the saturation of those pores. Water in those pores (which have a high surface energy), presents an oriented structure similar to the one in the ice (Figure 1), which, when interacting with those pores walls (Figure 2) causes microfissures. With the different microfissures generated in the adjacent pores join, the fissure spreads, and the piece tends to crack in a lamellar way, as is outlined in Fig. 7.

\subsection{Evaluation methodology}

The ceramic body water retention is Figure 5: Clay 400 microstructure, sinterized at the initial and essential stage of the $850^{\circ} \mathrm{C}$, non-resistant after 10 frosting-defrosting degradation process. The water absorpcycles (9971 times).

\subsection{Metodología de evaluación}

\section{cycles (9971 times).}

La retención del agua por la pieza cerámica es la etapa inicial y la condición indispensable para el proceso de degradación. La absorción de agua y la porosidad abiertas deben de ser controladas, porque la degradación del material sólo se produce cuando se halla saturado de agua. El grado de saturación depende de la cantidad de poros abiertos y de la cantidad de agua que contienen. Si la cantidad de agua absorbida es pequeña, la degradación no se produce, porque la tensión superficial en los poros abiertos es baja, y el material cerámico resiste perfectamente a esta tensión.

La porosidad influye más en la resistencia mecánica que en la resistencia a la congelación, como ocurre, por ejemplo, en la arcilla 100, cocida a $1000^{\circ} \mathrm{C}$, que es resistente a la congelación, a pesar de poseer mayor capa-

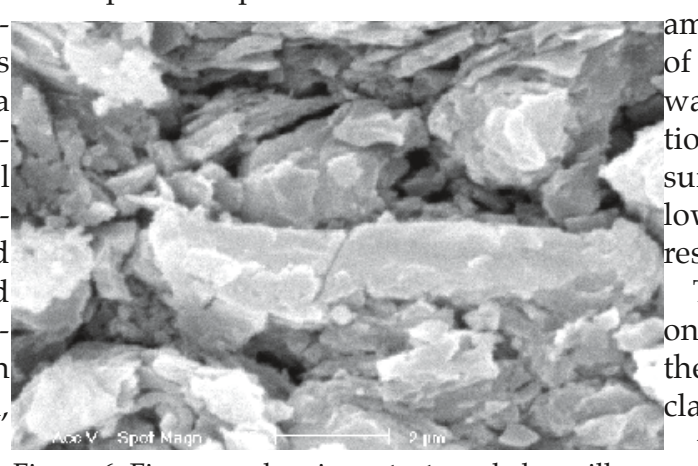

Figura 6: Fisuras en la microestrutura de la arcilla 400 , cocida a $850^{\circ} \mathrm{C}$ durante 24 horas, que no ha resistido a la acción de 10 ciclos de congelación descongelación (x 572).

Figure 6: Fissures in the microstructure of the clay 400 , sinterized at $850^{\circ} \mathrm{C}$ for 24 hours, non-resistant after 10 frosting-defrosting cycles (572 times). tion and the open porosity are parameters to be controlled, because the material degradation only occurs when it is The saturation degree depends on the amount of open pores and the quantity of water they have. If the quantity of water absorbed is small, the degradation will not take place, because the surface tension in the open pores is low, and the ceramic material perfectly resists this tension.

The porosity has a higher influence on the mechanical resistance than on the frost-resistance, as for instance, the lay 100 , sinterized at $1000^{\circ} \mathrm{C}$, presented a frost-resistance with a high water absorption and low mechanical resistance, being compared to the other clays under study, which are frost-resistant.

In the same way, a direct relation between the saturation coefficient and the degradation resistance of 
cidad de absorción de agua y menor resistencia mecánica que otras arcillas de este estudio, que también son resistentes a la congelación.

Tampoco se ha podido obtener una relación directa entre el coeficiente de saturación y la resistencia a la degradación de los materiales cerámicos sometidos a congelación - descongelación.

La tensión de ruptura por flexión de los productos cerámicos cocidos sí que influye sobre la resistencia a la congelación, porque en los poros cerrados se Figura 7: Representación esquemática del mecanis-
generan las microfisuras por la elevada tensión superficial que causa en dichos gelación cíclico de productos de cerámica roja. poros el agua con estructura orientada. La microfisura se produce, como es mechanism caused by the cyclical frost-defrost of natural, cuando esta tensión se sobre-the red ceramic products. pasa la que puede soportar el material.

De todos modos, la resistencia mecánica, a pesar de ser un factor significativo, no ofrece, por sí sola, una correlación satisfactoria con la resistencia a la congelación.

El estudio porosimétrico y, en especial, la determinación del volumen total y del tamaño medio de los mesoporos $(0,005 \mu \mathrm{m}-0,05 \mu \mathrm{m})$ ha sido, sin duda, la aportación más útil para avaluar la resistencia a la congelación de los materiales cerámicos porosos.

Basándose en la experimentación realizada en el presente estudio, se puede proponer un factor de degradación (FD), definido como la relación entre el volumen total de mesoporos, expresado en $10^{-3} \mathrm{~cm}^{3} / \mathrm{g}$, y el tamaño médio de los mesoporos, expresado en $\AA$, Según la ecuación:

$$
F D=V_{\text {Total de mesoporos }} \therefore T_{\text {Medio de mesoporos }}
$$

En la Fig. 8 se representa el factor de degradación de los materiales de arcilla cocida estudiados en este trabajo, calculado según la anterior ecuación, en función de su resistencia a la helada, expresada en número de ciclos de congelación descongelación.

Como puede observarse en la Fig. 8, cuánto menor es el factor de degradación, mayor es la resistencia a la helada. Es muy interesante observar también que las muestras resistentes a la helada posee un factor de degradación inferior a 100, salvo tres excepciones, que son resistentes poseyendo un factor de degradación mayor que 100. Estas muestras son: 1) Arcilla 200. $950^{\circ} \mathrm{C}-24 \mathrm{~h}$. 2) Arcilla $300.1000^{\circ} \mathrm{C}-24$ h. y 3) Arcilla $400.950^{\circ} \mathrm{C}-24 \mathrm{~h}$.

A propósito de estas excepciones, cabe señalar que la valoración del daño producido en las probetas después de cada ciclo de congelación - descongelación, se hace por inspección visual, de modo que pueden existir probetas que hayan sufrido daño estructural en su interior, sin mostrar signos visibles en su superficie.

A la vista de estos resultados experimentales, parece razonable considerar como resistentes a la helada los materiales de arcilla cocida, de cuyo estudio porosimétrico se deduzca un factor de degradación inferior a 100. Aquellos otros materiales que posean un factor de degradación superior a 100, deben ser sometidos a los ensayos de congelación - descongelación, para determinar, de modo directo, su resistencia a la helada.

Los resultados experimentales reunidos en la Fig. 8, inducen a aceptar que la resistencia a la helada depende de la ceramic materials submitted to frostdefrost could not be found.

The breaking load by flexion of the sinterized product does influence the frost-resistance, because the microstructures generated in the closed pores occur due to the high surface tension in the mentioned pores. This surface tension is caused by the water with an oriented structure, and, when it is higher than the one born by the material, generates fissures. Anyway, the mechanical resistance by itself does not present a satisfactory correlation with the frost-resistance, despite being an important factor.

The poresymetric study and, specially, the determination of the mesopores total volume and their average size has undoubtedly been the most useful evidence for the frostresistance evaluation of the porous ceramic materials.

On the basis of these observations, a degradation factor (DF) can be proposed, defined as the relation between the total volume of mesopores expressed by $10^{-3} \mathrm{~cm}^{3} / \mathrm{g}$, and their average size, expressed by $\AA$, according to the equation:

$$
F D={ }_{\text {total }} \text { Volume of mesopores. } . \text { Average } \text { Size of mesopores }
$$

Figure 8 presents the degradation factor of the red fired clays studied here, calculated according to the equation above, according to its frost resistance, expressed by the number of frost-defrost cycles.

As it can be seen in Fig. 8, the lower the degradation factor is, the higher the frost resistance is. It is also very interesting observing that the frost-resistant samples are present a degradation factor below 100, except for three exceptions, which are resistant with a degradation factor above 100 .

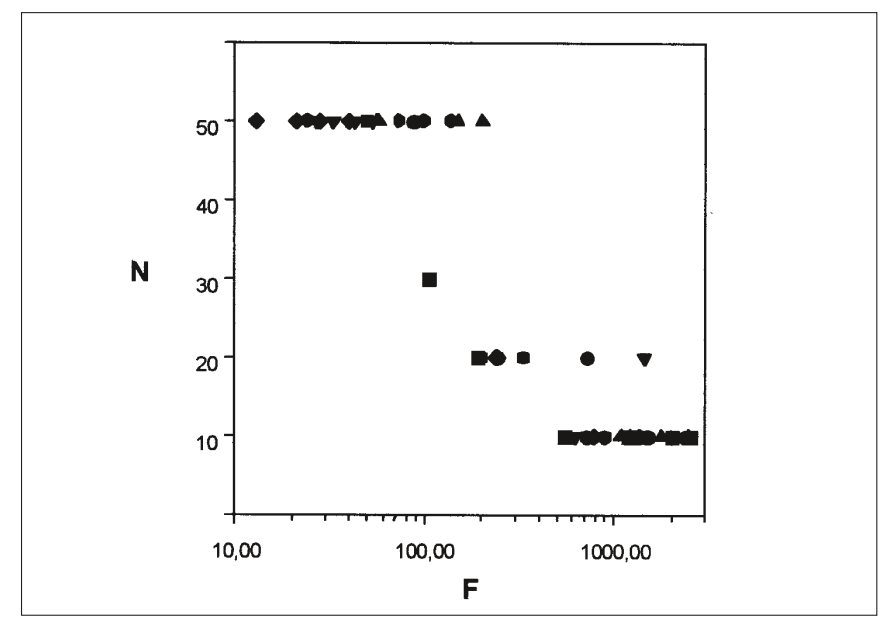

Figura 8: Relación entre el factor de degradación, de las arcillas en estudio en este trabajo, y el número de ciclos obtenidos en los ensayos de congelación - descongelación.

Figure 8: Relation between the degradation factor of the red clay materials studied in this paper, and the number of cycles obtained in the frosting-defrosting trials. ( $\mathrm{N}=\mathrm{No}$. of frosting-defrosting cycles; $\mathrm{F}=\log$ (degradation factor)) 
relación entre el volumen total de los mesoporos y su tamaño medio, definida como factor de degradación. Es interesante resaltar que este factor de degradación incluye indirectamente propiedades tales como absorción de agua, porosidad abierta y resistencia mecánica, ya que estas tres propiedades están directamente relacionadas con la porosidad del material, expresada en términos de volumen total y tamaño medio de los mesoporos.

A partir de esta constatación, se puede suponer que la resistencia al congelamiento dependa de la relación entre el volumen total de mesoporos y el tamaño medio de mesoporos. Cabe resaltar que el factor de degradación, aquí propuesto, contempla indirectamente propiedades como absorción de agua, porosidad abierta y resistencia mecánica, ya que estas tres propiedades están directamente relacionadas con la porosidad del material, expresada en términos de volumen total y tamaño medio de mesoporos.

El uso del factor de degradación, aquí propuesto, permitiría estimar la resistencia a la helada de los materiales cerámicos porosos mediante simples determinaciones porosimétricas, sin depender de los largos ensayos de congelación - descongelación, que tan poco compatibles son con el ritmo de la producción industrial.

\section{CONCLUSIONES}

En cuanto al modelo del mecanismo de degradación:

1. En el material cerámico, el agua que acompaña el crecimiento de una fisura, al congelarse en un poro abierto, tiene un efecto que depende del tamaño del poro: i) si el poro es muy grande, la fisura no siga necesariamente en la misma dirección, disipándose en energía y / o en dirección en el interior del poro, ii) si el poro es muy pequeño, existe dificultad de penetración del agua en el poro, por el tamaño de la molécula de agua, o, en caso de que penetrase, existe dificultad para la formación de una estructura orientada en la molecular de agua, no tensionando las paredes del poro.

2. Los poros de tamaño intermedios, al absorber agua, concentran la tensión preferentemente en la dirección de propagación de la fisura.

3. Cuanto mayor sea la proximidad de los mesoporos, mayor es la probabilidad de propagación de las fisuras, que conducen al colapso del material. La propagación de esas microfisuras, generadas en poros adyacentes, desencadenando la degradación de la pieza y su fractura laminar.

4. Ha sido posible confirmar este mecanismo de degradación mediante análisis microestructural por microscopia electrónica de barrido.

En cuanto a la metodología de evaluación:

1. De todas las propiedades analizadas - absorción de agua, densidad total, porosidad abierta, coeficiente de saturación, resistencia mecánica - la información más significativa para prever el comportamiento de materiales cerámicos al se sometidos a ciclos de congelación - descongelación, ha sido la determinación del volumen total de mesoporos y el tamaño medio de los mismos.

2. Fue posible proponer un factor de degradación (FD), basado en la relación entre el volumen total de los mesoporos y el tamaño medio de los mesoporos, llamado de factor de degradación:

$F D=V_{\text {Total de mesoporos }} \therefore T_{\text {Medio de mesoporos }}$
These samples are: 1) Clay $200.950^{\circ} \mathrm{C}$ - 24 hours. 2) Clay 300. $1000^{\circ} \mathrm{C}-24$ hours. And 3) Clay $400.950^{\circ} \mathrm{C}-24$ hours.

As for these exceptions, it can be said that the evaluation of the damage caused on the specimens after each frostdefrost cycle, is made by a visual analysis, so there can be specimens which have suffered an internal structural damage, without any visible signs on its surface.

According to that, it seems reasonable to consider the red clay materials, whose poresymetric study shows a degradation factor lower than 100. Those other materials that have a degradation factor above 100, must be submitted to frostdefrost trials to directly determine their frost resistance.

The experimental results, shown in Fig. 8, lead to the conclusion that frost-resistance depends on the relation between the mesopores total volume and the average mesopores size, defined as the degradation factor. It is interesting to highlight the fact that this degradation factor indirectly includes properties such as water absorption, open porosity, and mechanical resistance, as those three properties have a direct relationship with the material porosity, expressed in terms of total volume and average mesopores size.

Thus, the use of the degradation factor proposed here would permit to estimate those materials frost-resistance by the simple determination of the ceramic products poresymmetry, not depending on long frosting-defrosting trials which are so little compatible with industrial production rythm.

\section{CONCLUSIONS}

With regard to the degradation mechanism model:

1. In the ceramic material, the effect which takes place when the water accompanying the growth of a fissure freezes in an open pore, depends on the pore size: a) if the pore is very big, the fissure does not necessarily follow the same direction, vanishing into energy and/or in the direction of the inside of the pore, $b$ ) if the pore is very small, it would be difficult for water to penetrate the pore, due to the water molecule size, or in case it did penetrate, the formation of an oriented structure in the water molecules without tensing the pore walls would be difficult.

2. When absorbing water, the pores with a medium size concentrate the tension in the direction of the spreading of the fissure mainly.

3. The closer the mesopores are, the greater the probability of the spreading of the fissures is, leading to the collapse of the material. The spreading of those microfissures, generated in adjacent pores, triggers the piece degradation and its lamellar fracture.

4. It was impossible to find an evidence of this mechanism by means of the microstructural analysis with scanning electronic microscopy.

With regard to the evaluation methodology:

1. The most significant information obtained from all the properties analysed - water absorption, total density, open porosity, saturation rate, and mechanical resistance - in order to anticipate the materials behaviour when submitted to frosting and defrosting cycles were the mesopores total volume and the mesopores average size.

2. It was possible to propose a degradation factor (DF), based on the relationship between the mesopores total volume $(\mathrm{V})$ and the mesopores average size $(\mathrm{T})$ :

$D F={ }_{\text {Mesopores total }} V \therefore$ Mesopores averange $S$ 
Cuanto menor es el factor, mayor es la resistencia a la helada del material. Los materiales que poseen un factor de degradación menor de 100, han sido sin excepción, resistentes a la helada. Esto permite estimar de modo general el comportamiento a la helada, mediante la determinación del volumen total y del tamaño medio de los mesoporos.

3. Este índice comprende, de modo implícito, otros factores que concurren en la resistencia a la degradación de los materiales cerámicos, al ser sometidos a los ciclos de hielo - deshielo. Estos son: absorción de agua, densidad total, porosidad abierta, coeficiente de saturación y resistencia mecánica.

4. Una de las principales ventajas de la adopción de este índice es su rápida determinación, en comparación con la lentitud los ensayos de congelación - descongelación.

\section{BIBLIOGRAFÍA / REFERENCES}

1. M. V. Ramires, "Estudo de fenômenos que determinam a durabilidade de produtos de cerâmica vermelha em climas frios e úmidos". Universidade Federal do Rio Grande do Sul. Porto Alegre, Escola de Engenharia, Programa de Pós-Gradução em Engenharia de Minas, Metalúrgica e de Materiais. Tese de Doutorado. 1997.

2. L. Pauling, The nature of chemical bond. Cornell University. 1960.

3. E. M. Winhler, Stone: Properties, durability in man's enviroment. New York: Springer-Verlag. 1973.
The lower the degradation factor is, the higher the frostresistance is. Ceramic materials with a DF lower than 100 were, without exception, frost-resistant. This makes easier the evaluation of the ceramic materials generic behaviour, by the determination of the mesopores total volume and their average size.

3. This rate implicitly envisages other factors concurring in the ceramic materials degradation-resistance when submitted to frosting-defrosting cycles. These are: water absorption, total density, open porosity, saturation rate, and mechanical resistance.

4. One of the main advantages of the adoption of this rate is its quick determination, when compared to the long-term frosting-defrosting trials.

4. American Society for Testing and Materials. Standard Specification for Clay Roof Tiles, ASTM - C 1167/90. Philadelphia. 1990.

5. D. B. Honeyborne, "Frost action on natural stone". J. Brit. Ceram. Soc., n. 1, p. 222-230. 1963

6. E. P. Barrett, et all. "The determination of pore volume and area distribution in porous substances". J. Amer. Chem. Soc., n. 73, p.373. 1951.

7. M. M. Dubinin, "Progress in surface and membrane science". Academic Press, New York. 1975.

\section{FE DE ERRATAS}

En el Vol. 38 n 5, Sept.-Oct. 1999, Pag. 403. Titulo

“El procesado de polvos cerámicos manoparticulados", debe decir, nanoparticulados.

Pag. 427, por error se repetía la fig. 5, se reproduce la fig. 6 correspondiente.

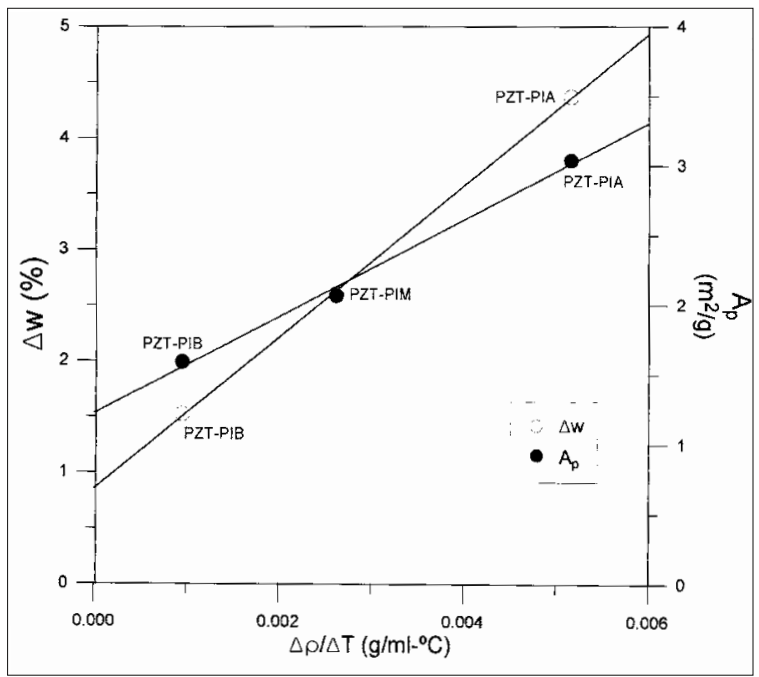

Figura 6. Curvas de variación de la pérdida de peso $(\Delta \mathrm{w})$ y área total de poros del polvo inicial $\left(A_{p}\right)$ en función de la variación de la densidad con la temperatura $(\Delta \rho / \Delta \mathrm{T})$, para los tres materiales cerámicos PZT. 